\title{
The Population Ecology of Iron Bacteria (Genus Ochrobium) in a Stratified Eutrophic Lake
}

\author{
By J. GWYNFRYN JONES \\ The Freshwater Biological Association, Windermere Laboratory, The Ferry House, \\ Ambleside, Cumbria LA22 OLP, U.K.
}

(Received 10 July 1980; revised 24 November 1980)

\begin{abstract}
Bacteria assigned to the genus Ochrobium have not yet been isolated in pure culture, but have been implicated in the deposition of ferric iron. These organisms have been observed in a number of lakes but the conditions under which active growth occurred have not been defined. A population of Ochrobium sp. developed in the anoxic hypolimnion of Esthwaite Water, a eutrophic lake in the English Lake District. Direct counts and experimental evidence obtained with this population suggested that the organism was capable of anaerobic growth. Inhibition of growth by chloramphenicol provided further evidence of its prokaryotic organization. The population overwintered in the sediment and at the onset of summer stratification, with deoxygenation of the hypolimnion, migrated into the water column. There was insufficient evidence to implicate Ochrobium sp. in ferric iron deposition.
\end{abstract}

\section{INTRODUCTION}

A few bacteria, including Thiobacillus ferrooxidans, obtain energy from ferrous ion oxidation, but a wide variety of bacteria exist which may deposit ferric iron without necessarily obtaining energy from the process. A number of possible mechanisms have been proposed (Glathe \& Ottow, 1972) including participation of peroxidases (Dubinina, 1978) and deposition associated with extracellular polymers (Ghiorse \& Hirsch, 1979). Many of these bacteria have been shown to be heterotrophs (Cullimore \& McCann, 1977; Kullmann \& Schweisfurth, 1978) but they include a number of morphologically distinct groups: budding and appendaged bacteria (Ghiorse \& Hirsch, 1977; Hirsch, 1968; Kucera \& Wolfe, 1957), filamentous bacteria (Dondero, 1975) and encapsulated bacteria of the family Siderocapsaceae (Zavarzin, 1974). The taxonomic position of the last group, particularly the genera Siderocapsa, Ochrobium and Naumanniella, is uncertain. Examination of authoritative works, including Beger (1949), Dorff (1934), Skuja (1956) and several later papers, suggests that some confusion might have arisen in their identification. Zavarzin (1974) questioned the validity of the family and considered Ochrobium to be a genus incertae sedis, possibly even comprising eukaryotic algae of the genus Pteromonas. More recently, Dubinina \& Zhdanov (1975) have proposed that the genus Siderocapsa is indistinguishable from the genus Arthrobacter. The original genus has been retained by some authors with species distinguished on morphological features (Svorcova, 1975, 1979). Organisms identified as Ochrobium sp. were reported to be prokaryotes containing gas vacuoles (Dubinina \& Kuznetsov, 1976) but have yet to be isolated in pure culture (Dubinina, 1976).

Organisms tentatively assigned to the genus Ochrobium have been observed in stratified lakes (Dubinina \& Kuznetsov, 1976; Drabkova, 1971; Jones, 1978) but details of their population ecology have not been investigated. Earlier observations (Jones, 1978) suggested that these organisms may be capable of anaerobic growth, but the sampling techniques were inadequate to confirm this. The present study examined the population ecology of Ochrobium 
sp. in more detail, to determine more precisely the depth at which the organism grew in the lake, and to provide more information on its physiological characteristics.

\section{METHODS}

Sampling site and procedure. Samples were taken over the deepest point (about $15.5 \mathrm{~m}$ ) of Esthwaite Water (English Lake District: $54^{\circ} 22^{\prime} \mathrm{N}, 2^{\circ} 59^{\prime} \mathrm{W}$ ), a eutrophic lake with a surface area of $1 \mathrm{~km}^{2}$ and a mean depth of $6.4 \mathrm{~m}$. The hypolimnion of the lake becomes deoxygenated during summer stratification. Water samples were taken initially with a Friedinger water bottle and subsampled into sterile glass bottles which were flushed with three times their own volume of water before immediate closure. When more precise depth sampling was required a peristaltic pump sampler was used (Cunningham \& Davison, 1980). Dissolved $\mathrm{O}_{2}$ concentration and temperature were measured in the field with a combination thermister $-\mathrm{O}_{2}$ electrode (Mackereth, 1964). A pressure transducer and a Schenk transparency meter of $0.5 \mathrm{~m}$ path length (Sauberer, 1958) were lowered simultaneously through the water column providing a plot of turbidity against depth. The turbidity profiles were used to determine sampling points. All measurements were made relative to the sediment-water interface. Sediment samples were taken with a Jenkin surface mud corer.

Chemical analyses. Total iron concentration was determined according to Mackereth et al. (1978) and $\mathrm{CO}_{2}$ by the head-space gas chromatographic technique described by Jones \& Simon (1980).

Direct counts of Ochrobium sp. Water samples were filtered through $25 \mathrm{~mm}$ diameter $(0.45 \mu \mathrm{m}$ pore size $)$ Millipore membrane filters. These were dried at $60^{\circ} \mathrm{C}$ and cleared with cedarwood oil, and the organisms were counted at a magnification of $\times 320$ under bright-field illumination. A total of 400 organisms were counted, and since these were randomly distributed on the surface of the membrane (Jones, 1975) the $95 \%$ confidence limits of the count were $\pm 10 \%$ of the mean. Filaments of Leptothrix sp. in the samples were counted at the same time. It was impossible to obtain reliable quantitative estimates of Ochrobium cells in the sediment but their distribution was determined on agar-coated glass slides. The slides were heated in a bunsen flame, allowed to cool and dipped in $2 \%(\mathrm{w} / \mathrm{v})$ agar in distilled water held at $60^{\circ} \mathrm{C}$. Excess agar was drained off in the vertical position and the slides were stored horizontally in a high-humidity chamber until required. They were inserted into core samples of sediment so that $2 \mathrm{~cm}$ remained above the surface, and incubated at $8{ }^{\circ} \mathrm{C}$ for $24 \mathrm{~h}$. The position of the sediment-water interface was marked, the slides were removed and the Ochrobium cells were counted along transects measured with a microscope stage vernier. The effect of inhibitors on the growth of Ochrobium sp. on the slides was determined by pretreating the overlying water, and allowing the inhibitors to diffuse into the sediment for $24 \mathrm{~h}$, before inserting the slides. A second addition of inhibitor was made as the slides were inserted.

Growth experiments. A 51 container was filled and continuously flushed with hypolimnetic water in the boat, using the peristaltic pump sampler. A universal bottle, previously flushed with $\mathrm{N}_{2}$ and with a butyl rubber insert in the cap, was then opened, flushed and sealed under water in the container. This ensured that the sample was not contaminated with $\mathrm{O}_{2}$. Rapid deposition of ferric iron occurred in contaminated samples. The samples were incubated in the laboratory at $20^{\circ} \mathrm{C}$. Control samples were counted at zero time and the effect of $\mathrm{O}_{2}$ was determined by the introduction of $1 \mathrm{ml}$ air into selected bottles.

ATP analyses. A sensitive modification of the luciferin-luciferase procedure (Jones \& Simon, 1977) was used, with the samples injected directly into boiling Tris buffer $\mathrm{pH} 7 \cdot 8$. Internal standards were analysed with each sample.

\section{RESULTS AND DISCUSSION}

When pure cultures of bacteria are not available, identification based solely on morphological characteristics must be considered to be tentative. Ochrobium is one of several genera of encapsulated and otherwise morphologically distinct bacteria which are identified in this way. The organisms described in this study (Fig. 1) and by Jones (1978) are morphologically similar to those assigned to the genus Ochrobium by Dubinina \& Kuznetsov (1976), although it must be recognized that some confusion might have arisen in the identification of encapsulated bacteria since their original descriptions (see Introduction).

At the onset of summer stratification in Esthwaite Water the release, and immediate oxidation, of ferrous ions from the sediment increased the turbidity in the overlying water. Ochrobium sp. capsules and Leptothrix sp. filaments were found in the turbid zone, and although their numbers were relatively low (2 orders of magnitude lower than the Ochrobium sp. count in August and 4 orders of magnitude lower than the count of total bacteria), their presence suggested either growth in situ or an upward migration from the sediment (Fig. 2). 

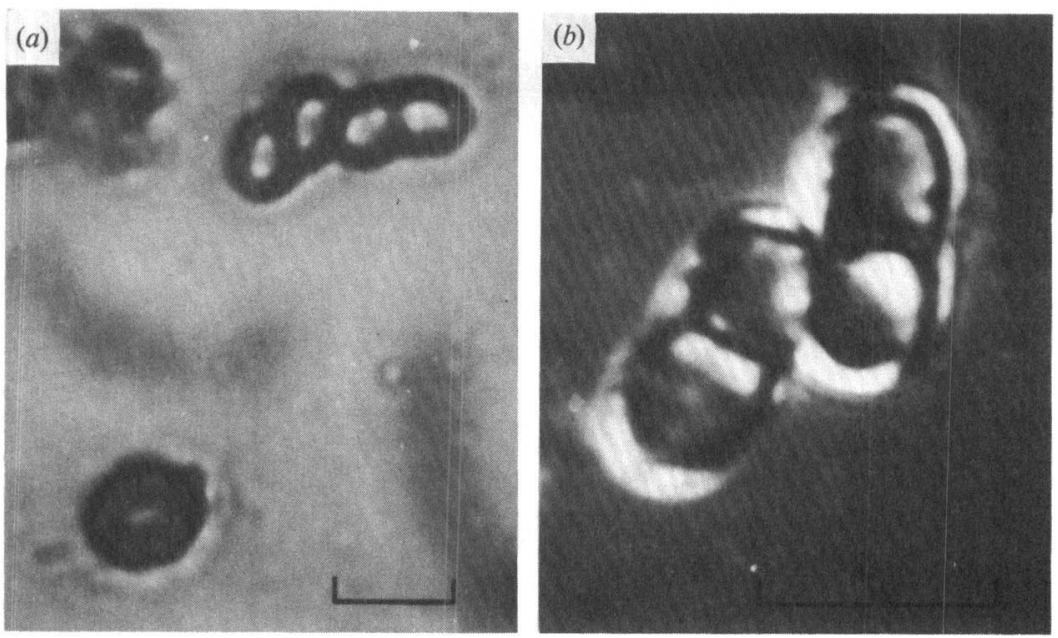

Fig. 1. Photomicrographs of Ochrobium sp. capsules from the hypolimnion of Esthwaite Water. Water samples were filtered through a $0.45 \mu \mathrm{m}$ pore size cellulosic membrane filter which was then air dried and cleared with cedarwood oil: (a) bright-field microscopy; $(b)$ interference contrast microscopy. The bar markers represent $5 \mu \mathrm{m}$.

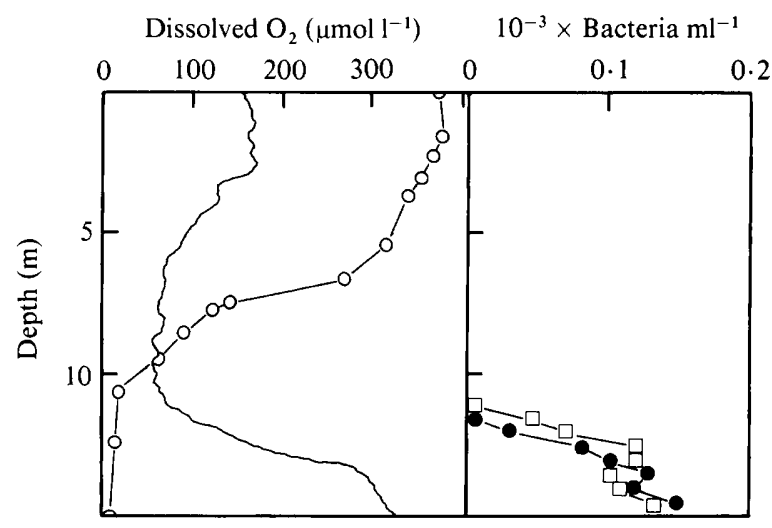

Fig. 2. Distribution of dissolved $\mathrm{O}_{2}(\mathrm{O})$, turbidity (continuous line), Ochrobium sp. (O) and Leptothrix sp. ( $\square$ ) with depth in Esthwaite Water during summer stratification (13 July 1978).

Within a month the zone of iron oxidation and the Ochrobium sp. and Leptothrix sp. populations had moved upward into the water column and peaks were found at depths of 12 to $13 \mathrm{~m}$ (Fig. 3). The release of ferrous ions into the anoxic hypolimnion of Esthwaite Water was first reported by Mortimer $(1941,1942)$ and the use of the transparency meter to determine the zone of iron oxidation and the dynamics of iron transport in the lake has been discussed in detail by Davison et al. (1981). The turbidity profiles indicate the depth at which ferrous ions were oxidized and therefore the depth to which $\mathrm{O}_{2}$ must penetrate periodically, even if it was analytically undetectable (see Fig. 3 and subsequent Figures). Within a week the hypolimnion had become deoxygenated further, $\mathrm{CO}_{2}$ concentrations had increased and the zone of iron oxidation had developed a sharp peak (Fig. 4a). The Leptothrix sp. and Ochrobium sp. populations had increased by an order of magnitude and were now separated into two distinct zones, the former above and the latter just below the peak of oxidized iron. This suggested that Leptothrix sp. had a greater requirement for $\mathrm{O}_{2}$ (Jones, 1975, 1978), and although the genus has been observed frequently in the metalimnia of stratified lakes it has 


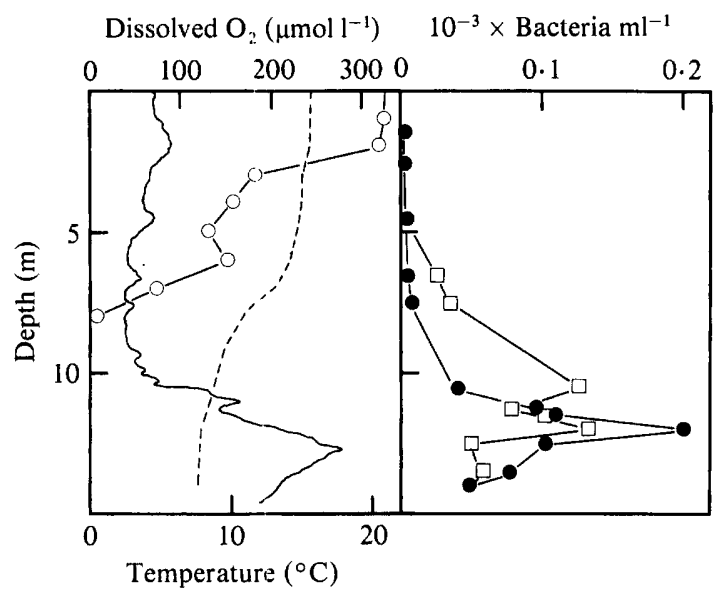

Fig. 3. Distribution of dissolved $\mathrm{O}_{2}(\mathrm{O})$, turbidity (continuous line), temperature (broken line), Ochrobium sp. (○), and Leptothrix sp. () with depth in Esthwaite Water (9 August 1978).

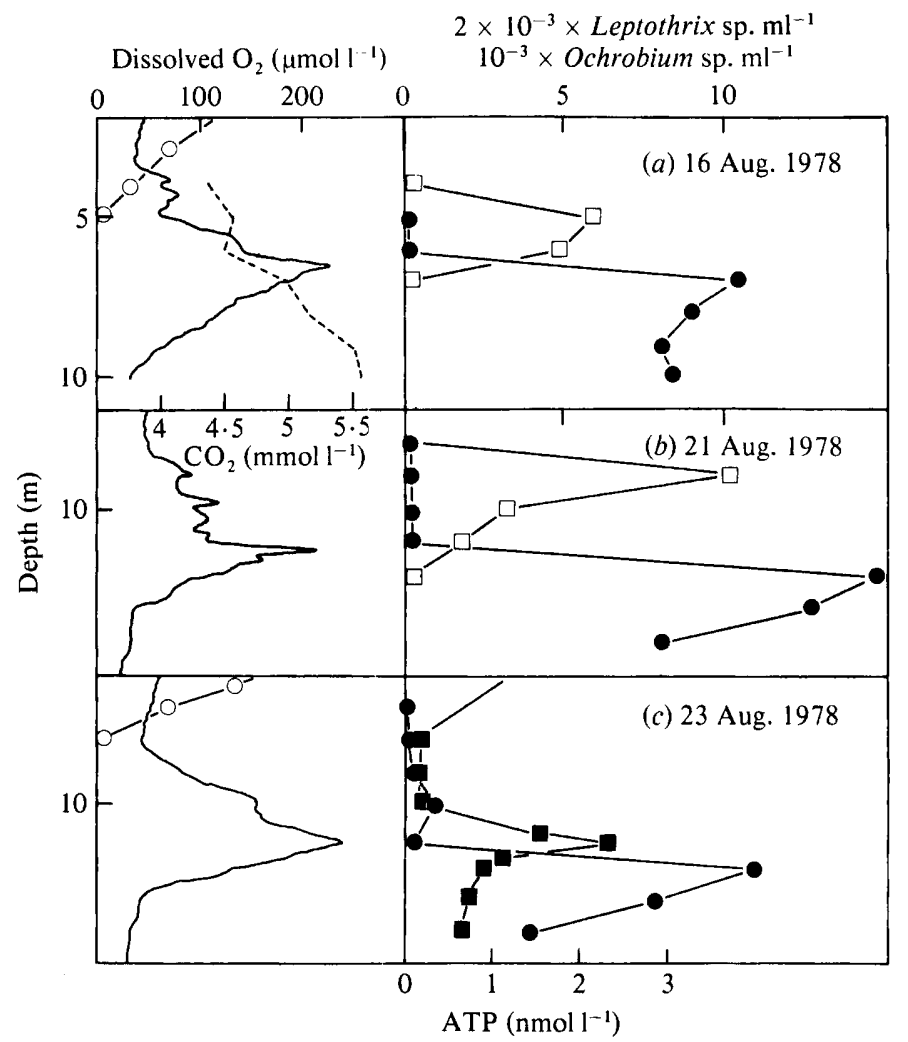

Fig. 4. Distribution of dissolved $\mathrm{O}_{2}(\mathrm{O})$, turbidity (continuous line), dissolved $\mathrm{CO}_{2}$ (broken line),

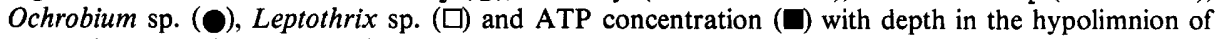
Esthwaite Water (August 1978).

also been observed in surface films of ponds (Frolund, 1977) where there was a plentiful supply of $\mathrm{O}_{2}$. The difference in the depth distribution of Ochrobium sp. and Leptothrix sp. in Esthwaite Water was even more marked a few days later (Fig. $4 b$ ) and during periods of calm it was possible to make rough estimates of the net increases in the population. During the 


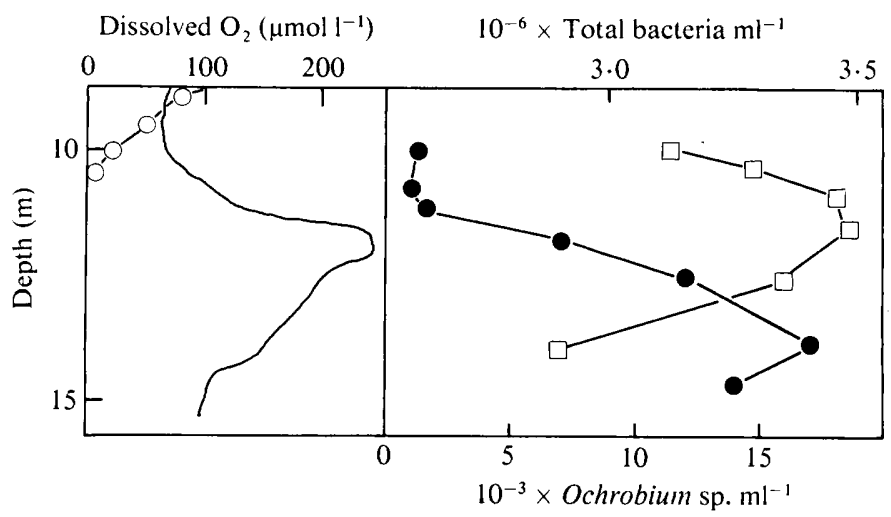

Fig. 5. Distribution of dissolved $\mathrm{O}_{2}(\mathrm{O})$, turbidity (continuous line), Ochrobium sp. (O) and total bacteria ( $\square$ ) with depth in the hypolimnion of Esthwaite Water (25 July 1980).

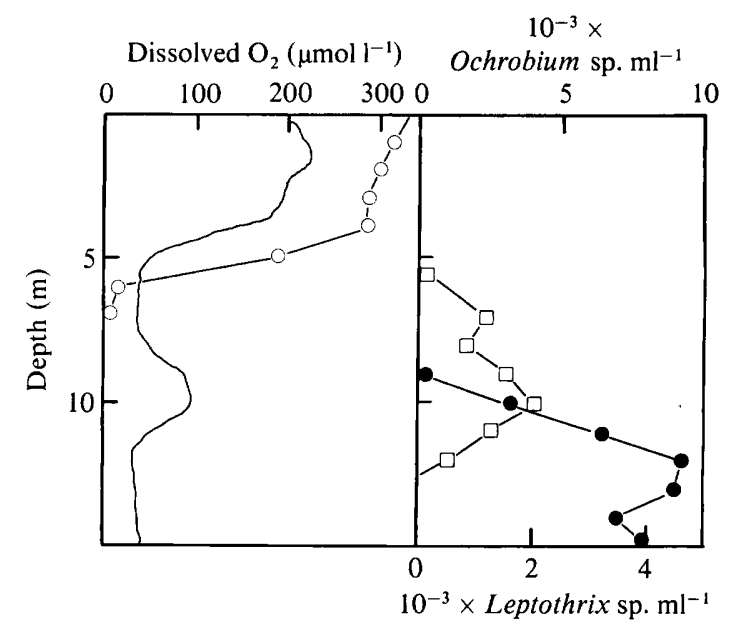

Fig. 6. Distribution of dissolved $\mathrm{O}_{2}(\mathrm{O})$, turbidity (continuous line), Ochrobium sp. (O) and Leptothrix sp. () with depth in Esthwaite Water (7 September 1978).

period of most rapid growth this was equivalent to an apparent generation time for Ochrobium sp. of $29 \mathrm{~h}$, but this did not allow for losses due to grazing and population migration. These increases occurred in the apparent absence of $\mathrm{O}_{2}$. The peak of ATP concentration at these depths coincided exactly with the peak of iron oxidation (Fig. $4 c$ ), suggesting that other bacteria were closely associated with this zone and that the population of Ochrobium sp. did not make a significant contribution to the total biomass as measured by ATP concentration at this peak region. Further examination of this zone revealed that the total bacterial counts were highest at the peak of iron oxidation (Fig. 5). Bacteria formed the major component of the biomass in the anoxic region of the hypolimnion. This could be attributed to the absence of sufficient light for algal growth and of sufficient $\mathrm{O}_{2}$ to support a significant ciliate population. The ciliates that did grow in the anoxic water accounted for approximately $10 \%$ of the total biomass (B. Finlay, personal communication). The Ochrobium sp. population of up to $1.5 \times 10^{4}$ cells $\mathrm{ml}^{-1}$ constituted only a small percentage of the total bacterial population $\left(>5 \times 10^{6} \mathrm{ml}^{-1}\right)$ at these depths (Jones, 1978) and only made a small contribution to the total biomass.

Later in the season, wind-induced turbulence dispersed the zone of iron oxidation and the population of Ochrobium sp. (Fig. 6). The cells disappeared from the water column at 
Table 1. Counts of Ochrobium sp. colonizing agar-coated slides inserted into profundal sediment cores of Esthwaite Water and incubated for $24 \mathrm{~h}$ at $8^{\circ} \mathrm{C}$

The results are expressed as means $\pm 95 \%$ confidence limits, based on 30 counts.

\begin{tabular}{ccc}
$\begin{array}{c}\text { Depth in sediment } \\
(\mathrm{mm})\end{array}$ & $\begin{array}{c}\text { Ochrobium sp. count } \\
\text { (organisms cm }\end{array}$ \\
\cline { 2 - 3 } 0 & Nanuary 1980 & June 1980 \\
1.0 & ND & $107 \pm 89$ \\
1.5 & $472000 \pm 166000$ & $38 \pm 58$ \\
2.0 & $120000 \pm 100000$ & $19 \pm 38$ \\
3.0 & $4700 \pm 6000$ & $11 \pm 13$ \\
4.0 & $400 \pm 420$ & 0
\end{tabular}

ND, Not detectable (but a heavy deposition of ferric iron hindered microscopic observation).

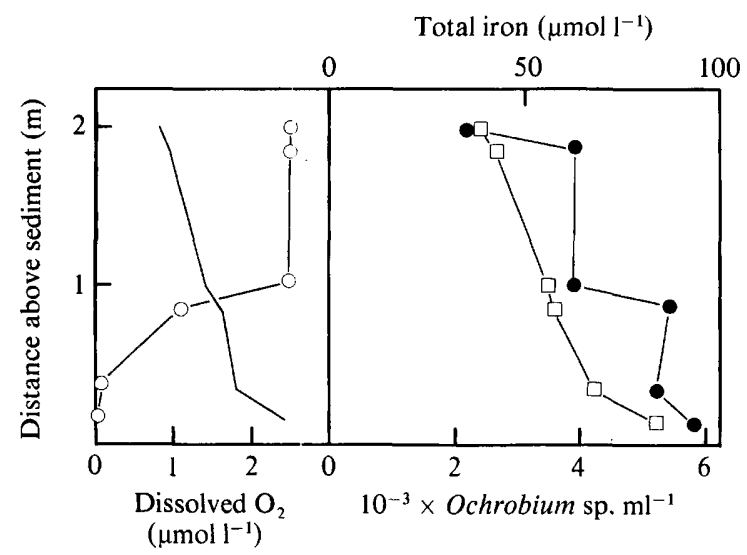

Fig. 7. Distribution of dissolved $\mathrm{O}_{2}(\mathrm{O})$, turbidity (continuous line), Ochrobium sp. (O) and total iron concentration $(\square)$ with depth, at the onset of summer stratification and deoxygenation of the profundal water in Esthwaite Water (9 June 1980).

overturn. During winter, Ochrobium sp. cells were found in large numbers a few millimetres below the surface of the sediments in the profundal zone (Table 1), but at the onset of summer stratification, with the reduction of $\mathrm{O}_{2}$ tension and release of iron, numbers in the sediments decreased dramatically (Table 1) and Ochrobium sp. was found in the water column once more (Fig. 7). The decrease in numbers in the sediment, if converted to a volume basis, would be equivalent to a release of $2 \times 10^{6}$ cells $\mathrm{ml}^{-1}$ over the $2 \mathrm{~m}$ of water column shown in Fig. 7 . The actual numbers observed were much lower than this. There were several possible explanations for this disparity, including: $(a)$ the possibility that not all the cells moved out of the sediment; (b) Ochrobium sp. was being actively grazed (ciliates containing large numbers of encapsulated iron bacteria have been observed on the agar-coated slides); $(c)$ the slide technique may have encouraged growth and therefore the population in the sediment was overestimated. It was clear, however, that the Ochrobium sp. cells overwintered in the profundal sediments and moved into the water column, presumably assisted by their gas vacuoles (Dubinina \& Kuznetsov, 1976), as anoxic conditions developed. The size of this initial inoculum of the water column varied considerably from year to year, being 150

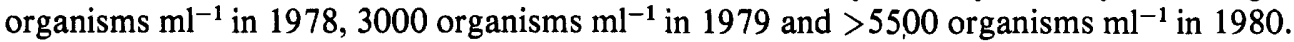

The development of Ochrobium sp. on agar-coated slides incubated in sediment cores was completely inhibited by formaldehyde, suggesting that growth rather than passive attachment 
Table 2. Counts of Ochrobium sp. colonizing agar-coated slides inserted into profundal sediment cores of Esthwaite Water after $24 \mathrm{~h}$ pretreatment with inhibitors

The sediment cores were collected in February 1980. The results are expressed as means $\pm 95 \%$ confidence limits, based on 30 counts.

\begin{tabular}{|c|c|c|}
\hline \multirow{3}{*}{$\begin{array}{l}\text { Inhibitor } \\
\text { (final concentration) }\end{array}$} & \multicolumn{2}{|c|}{$\begin{array}{c}\text { Ochrobium } \text { sp. count } \\
\left(10^{-3} \times \text { organisms } \mathrm{cm}^{-2}\right)\end{array}$} \\
\hline & \multicolumn{2}{|c|}{ Incubation conditions } \\
\hline & $8^{\circ} \mathrm{C}, 42 \mathrm{~h}$ & $20^{\circ} \mathrm{C}, 8 \mathrm{~h}$ \\
\hline $\begin{array}{l}\text { aldehyde }(4 \%, \mathrm{v} / \mathrm{v}) \\
\text { amphenicol }\left(100 \mathrm{mg} \mathrm{l}^{-1}\right) \\
\text { ione }\left(100 \mathrm{mg} \mathrm{l}^{-1}\right)\end{array}$ & $\begin{array}{l}316 \pm 56 \\
0 \\
2 \cdot 7 \pm 3 \cdot 2 \\
255 \pm 62\end{array}$ & $\begin{array}{r}1400 \pm 43 \\
0 \\
50 \pm 28 \\
1020 \pm 15\end{array}$ \\
\hline
\end{tabular}

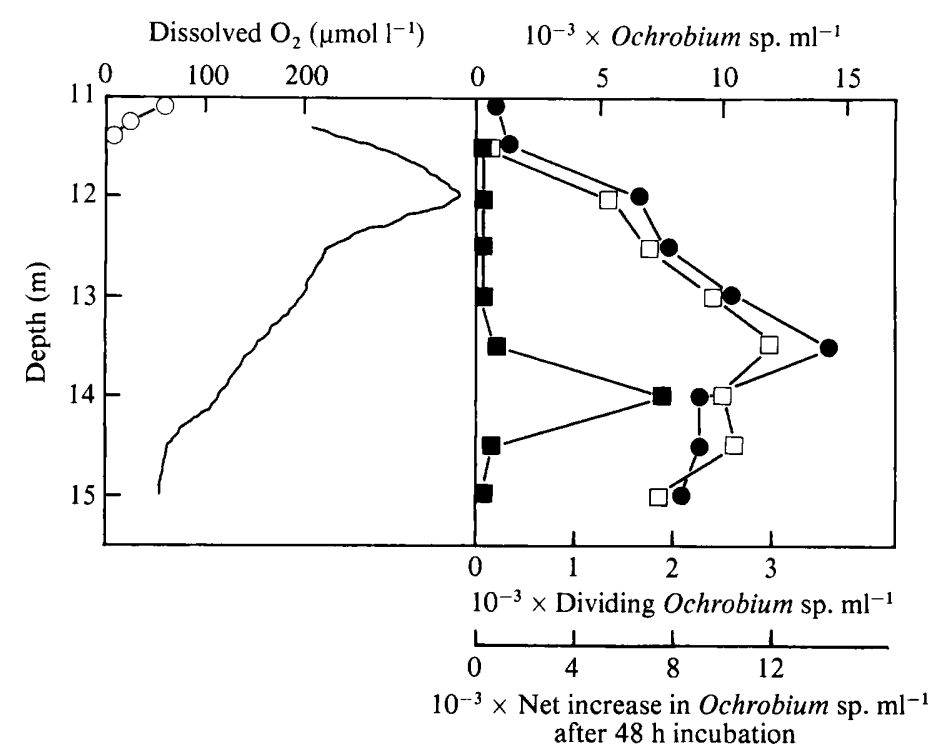

Fig. 8. Distribution of dissolved $\mathrm{O}_{2}(\mathrm{O})$, turbidity (continuous line), total Ochrobium sp. (O) and dividing Ochrobium sp. ( $\square$ ) with depth in Esthwaite Water, and net change in numbers of Ochrobium $\mathrm{sp}$. after incubation of closed samples for $48 \mathrm{~h}$ at $20^{\circ} \mathrm{C}$ under anaerobic conditions ( $\square$ ) (28 July 1980).

occurred (Table 2). Chloramphenicol inhibited development almost completely, whereas actidione had no effect (Table 2). These results suggested that the organism was a prokaryote, in agreement with the ultrastructural evidence presented by Dubinina \& Kuznetsov (1976).

The conditions under which active growth of Ochrobium sp. occurred were less easily defined. Dubinina \& Kuznetzov (1976) and Drabkova (1971) have reported Ochrobium sp. populations in both oxygenated and deoxygenated water and Dubinina (1976) referred to the growth of encapsulated iron bacteria in water to which $\mathrm{O}_{2}$ penetrated but was not analytically detectable. The results obtained in Esthwaite Water suggested that Ochrobium sp. was capable of anaerobic growth; the absence of $\mathrm{O}_{2}$ as measured with an electrode in the water column was confirmed by electrochemical analysis (W. Davison, personal communication). The frequency with which dividing cells occur has been shown to be related to growth rates of planktonic bacteria (Hagström et al., 1979) and further examination of samples from the hypolimnion of Esthwaite Water revealed larger numbers of dividing cells in the permanently anoxic water than in the upper hypolimnion, where occasional turbulent penetration of $\mathrm{O}_{2}$ occurred (Fig. 8). Confirmation of anaerobic growth was obtained when water samples were 
incubated in the laboratory. Growth only occurred in those samples that had been collected and incubated in the absence of $\mathrm{O}_{2}$ (Fig. 8). Introduction of $1 \mathrm{ml}$ air into the vessels resulted in a complete cessation of growth and often a drastic reduction in numbers. The apparent generation times obtained were longer (about $50 \mathrm{~h}$ ) than those observed in the field. The depth at which the organism grew in the sediments also suggested anaerobic or at least microaerophilic metabolism. The most careful measurements have suggested that dissolved $\mathrm{O}_{2}$ penetrates only a few millimetres into sediments (Revsbech et al., 1980) even though high $E_{\mathrm{h}}$ values were observed to greater depths.

Planktonic bacteria which appear to be associated with iron and manganese transformations are often difficult to isolate. Gregory et al. (1980) concluded that the microbial structures they observed (Metallogenium sp.) were not a living form of the organism. In the present study, growth of Ochrobium sp. was observed but the physiological characteristics of the organism will not be resolved until it is obtained in pure culture. Until then it cannot be assumed that it actively deposits ferric iron around the capsule. Such a deposition may be a chemical artefact caused by the microscopic examination of Ochrobium sp. in the presence of $\mathrm{O}_{2}$ after removal of cells from anoxic water rich in ferrous ions.

I am very grateful to S. Irwin, B. M. Simon, R. Meighan and S. Gardener who have helped at various stages with the microbiological analyses, to E. Rigg who performed the total iron analyses, to W. Davison and S. I. Heaney for valuable discussions on the iron chemistry of Esthwaite Water, to S. I. Heaney who provided the $\mathrm{O}_{2}$ results for Fig. 2, and to Miss E. M. Evans who typed the script. This research was financed by a grant-in-aid from N.E.R.C.

\section{REFERENCES}

BEgER, H. (1949). Beiträge zur Systematik und geographischen Verbreitung der Eisenbakterien. Berichte der Deutschen botanischen Gesellschaft 62 , 7-13.

Cullimore, D. R. \& McCANN, A. E. (1977). The identification, cultivation and control of iron bacteria in ground water. In Aquatic Microbiology, pp. 219-261. Edited by F. A. Skinner \& J. M. Shewan. London: Academic Press.

Cunningham, C. R. \& Davison, W. (1980). An opto-electronic sediment detector and its use in the chemical micro-profiling of lakes. Freshwater Biology 10, 413-418.

Davison, W., Heaney, S. I., Talling, J. F. \& Rigg, E. (1981). Seasonal transformations and movements of iron in a productive English lake with deep-water anoxia. Schweizerische Zeitschrift für Hydrologie 42, 196-224.

DoNDERo, N. C. (1975). The Sphaerotilus-Leptothrix group. Annual Review of Microbiology 29, 407-428.

DORFF, P. (1934). Die Eisenorganismen. Pflanzenforschung 16, 1-62.

DrabKova, V. G. (1971). Iron bacteria in some lakes of the Karelian isthmus. Hydrobiological Journal 7, 21-27.

Dubinina, G. A. (1976). Ecology of freshwater iron bacteria. Biological Bulletin 3, 473-489.

DubininA, G. A. (1978). Mechanism of oxidation of divalent iron and manganese by iron bacteria growing in neutral medium. Mikrobiologiya 47, 591-599.

Dubinina, G. A. \& Kuznetsov, S. I. (1976). The ecological and morphological characteristics of microorganisms in Lesnaya Lamba (Karelia).
Internationale Revue der gesamten Hydrobiologie 61, 1-19.

Dubinina, G. A. \& Zhdanov, A. V. (1975). Recognition of the iron bacteria "Siderocapsa" as Arthrobacters and description of Arthrobacter siderocapsulatus sp.nov. International Journal of Systematic Bacteriology 25, 340-350.

Frolund, A. (1977). The seasonal variation of the neuston of a small pond. Botanisk Tidsskrift $\mathbf{7 2}$, 45-56.

Ghiorse, W. C. \& Hirsch, P. (1977). Iron and manganese deposition by budding bacteria. In Proceedings of the 3rd International Symposium of Environmental Biogeochemistry and Geomicrobio$\operatorname{logy} 3$, pp. 897-909. Edited by W. E. Krumbein. Ann Arbor: Ann Arbor Science.

Ghiorse, W. C. \& Hirsch, P. (1979). An ultrastructural study of iron and manganese deposition associated with extracellular polymers of Pedomicrobium-like budding bacteria. Archives of Microbiology 123, 213-226.

Glathe, H. \& Ottow, J. C. G. (1972). Ecological and physiological aspects of the mechanism of iron oxidation and ochreous deposit formation-a review. Zentralblatt für Bakteriologie, Parasitenkunde, Infektionskrankheiten und Hygiene (Abteilung III) 127, 749-769.

Gregory, E., Perry, R. S. \& Staley, J. T. (1980). Characterization, distribution and significance of Metallogenium in Lake Washington. Microbial Ecology 6, 125-140.

HagSTröm, A., Larsson, U., Horstedt, P. \& NORMARK, S. (1979). Frequency of dividing cells, a new approach to the determination of bacterial 
growth rates in aquatic environments. Applied and Environmental Microbiology 37, 805-812.

Hirsch, P. (1968). Biology of budding bacteria: IV. Epicellular deposition of iron by aquatic budding bacteria. Archiv für Mikrobiologie 60, 201-216.

JoNes, J. G. (1975). Some observations on the occurrence of the iron bacterium Leptothrix ochracea in fresh water, including reference to large experimental enclosures. Journal of Applied Bacteriology 39, 63-72.

JoNES, J. G. (1978). The distribution of some freshwater planktonic bacteria in two stratified eutrophic lakes. Freshwater Biology 8, 127-140.

JoNES, J. G. \& SimON, B. M. (1977). Increased sensitivity in the measurement of ATP in freshwater samples with a comment on the adverse effect of membrane filtration. Freshwater Biology 7, 253260.

Jones, J. G. \& Simon, B. M. (1980). Decomposition processes in the profundal region of Blelham Tarn and the Lund tubes. Journal of Ecology 68, 493-512.

KuCERA, S. \& Wolfe, R. S. (1957). A selective enrichment method for Gallionella ferruginea. Journal of Bacteriology 74, 344-349.

Kullman, K. H. \& Schweisfurth, R. (1978). Iron oxidising, rod-shaped bacteria. II. Quantitative study of metabolism and iron oxidation using iron(II) oxalate. Zeitschrift für allgemeine Mikrobiologie 18 , 321-327.

MACKeRETH, F. J. H. (1964). An improved galvanic cell for determination of oxygen concentrations in fluids. Journal of Scientific Instruments 41, 38-41.

Mackereth, F. J. H., Heron, J. \& Talling, J. F. (1978). Some revised methods of water analysis for limnologists. Freshwater Biological Association Scientific Publication No. 36.

Mortimer, C. H. (1941). The exchange of dissolved substances between mud and water in lakes. I and II. Journal of Ecology 29, 280-329.

Mortimer, C. H. (1942). The exchange of dissolved substances between mud and water in lakes. III and IV. Journal of Ecology 30, 147-201.

Revsbech, N. P., Jørgensen, B. B. \& Blackburn, T. H. (1980). Oxygen in the sea bottom measured with a microelectrode. Science 207, 1355-1356.

SAUBERER, F. (1958). Zur Durchsichtigkeitsmessung im Gewässern. Wetter und Leben 10, 67-69.

Skuja, H. (1956). Taxonomische und biologische Studien über das Phytoplankton schwedischer Binnengewässer. Nova acta Regiae Societatis scientiarum upsaliensis Ser. 4, 16, 1-404.

Svorcova, L. (1975). Iron bacteria of the genus Siderocapsa in mineral waters. Zeitschrift für allgemeine Mikrobiologie 15, 553-557.

SvorcovA, L. (1979). Iron bacteria of the family Siderocapsaceae. Archiv für Hydrobiologie 87, 423-452.

Zavarzin, G. A. (1974). Family Siderocapsaceae. In Bergey's Manual of Determinative Bacteriology, 8th edn, pp. 464-468. Edited by R. E. Buchanan \& N. E. Gibbons. Baltimore: Williams \& Wilkins. 